\title{
THE MOSLEM POPULATION OF BOMBAY
}

ThE city of Bombay, the principal seaport of Western India, is situated on an island which covers an area of 22.48 square miles. This island is one of a group and in former days was itself composed of seven small islands. Bombay is connected with another larger island called Salsette and with the mainland by means of causeways and railway embankments. India is no doubt crowded with places of extreme interest, yet none surpasses Bombay in natural picturesqueness, beauty, and salubrity of situation. The city, which was recently appropriately called "Bombay the Beautiful," possesses natural advantages as a trading centre and may also be singled out as a favourable site for habitation. Its growth during the last sixty years has been very remarkable. All the tribes of Western India seem to have flocked to it in search of work or a home. Its population, when it passed from Portugal to England in 1661, was about 10,000 ; fourteen years later it had risen to 60,000 ; and in 1836 it was 236,000 . I am not in a position to forecast what the next year's official census will be, but the figures of the census of 1906, which give the total population of the city as 977,822 , are quite sufficient for our purpose. The average of inhabitants per acre, according to them, is sixty-eight; but in the most congested districts in the heart of the city this average rises to 712 to the acre.

The chief religions of Bombay are Hinduism, Islam, Zoroastrianism, Judaism, and Christianity. Sixty-two different dialects are spoken, of which the principal are Marathi, spoken by 51 per cent. of the total population; Gujarati, spoken by 26 per cent., Urdu, spoken by 15 per cent. ; and English by 2 per cent. 
The Bombay Moslem of to-day is very accessible. Education has awakened in him a desire to snap asunder the fetters which obstructed his progress for so long in the past. By last year the total number of Urdu schools was twenty-eight, twenty-five for boys and three for girls, while in 1895 they only had two. The number of Moslem students taking higher education is also steadily increasing. The interest shown by Moslems in the education of their youth has become considerably accentuated of late years. In 1860 there were only three Moslem pupils in the Bombay city colleges, fifteen students in the High, nineteen in the Middle, sixty-six in the Primary, and twenty-six in the Special schools. In 1880 the figures rose to six College students, and seventy in the High, 164 male and five female pupils in the Middle, 185 male and eight female in the Primary, and seventy male pupils in the Special schools. In 1909, we find ninety-three Moslem male College students and only one female, 786 male and fourteen female in the High School, 268 male and six female in the Middle School, and 3,448 male and 1,241 female Primary School pupils. These figures would have been considerably higher if the wealthy and patriotic Moslem philanthropists had raised more endowments to help the children of their co-religionists to take the fullest advantage of the system of higher education. Hence the Moslem of to-day has imbibed something of the spirit of the age which makes him long to be educated and aspire after a high position in the state as well as in society. We also may add that never before was there a better and more magnificent door opened in Bombay for the advance of our Redeemer's Kingdom.

For working among the Moslems in Bombay the missionary must know Urdu and Arabic. It may also be useful if he has acquired some knowledge of Gujarati. Urdu is easily picked up by Europeans from the Roman character, in which it is printed for those who may not be able to afford the time to exert themselves to acquire a knowledge of the Persian character of the Devanagri. By this the missionary will find that in a very short time he can render invaluable service. 
The Arabic-speaking community in Bombay numbers 6,119 . In addition to this, there are also about 3,000 Jews who speak nothing else but Arabic. The communities whose language is Urdu, or a corrupt form of it, are:-Bohras, numbering 11,992; Julhais, 7,026 ; Khojas, 10,688 ; Maiman, 17,585 ; Pathan, 7,638 ; Shaikh, 89,522; and others, 5,177. These may be divided into two main sections, those of foreign extraction and those of Hindu descent. The former include :-

1. Shaikhs.-The majority of Moslem converts have a tendency to describe themselves as Shaikhs of the tribe of Quraish. The title Shaikh belongs strictly only to three branches of the tribe of Quraish, viz., the Siddiqi, who claim descent from the first Khalifah ; the Faruqi, who claim descent from the second Khalifah; and the 'Abbasi, a descendant of 'Abbas one of Mohammed's nine uncles. Members of this class are sober, fairly truthful and honest, fond of show and pleasure and careless about their money dealings. According to a North Indian Urdu proverb, "The Shaikh is as sly as a crow." Many of them are devout Moslems, and almost all are anxious to give their children a kind of education.

2. Saiyids.-Members of this class claim their descent from Fatimah and 'Ali, the daughter and son-in-law of Mohammed. Their men mark their high birth by placing the title Saiyid or Mir before, and Shah after their names, and among women the title Begam is added after the name. As a class Saiyids are truthful, honest, sober, idle, fond of pleasure and thriftless, a quality which they mis-name resignation, as their common saying expresses: "If we have money, we are lords; if we have no money, we are beggars; if we die, we are saints." In religion, Saiyids are either Sunnis or Shi'ahs. They are by their profession obliged to show that they are religious, and as a class they are careful to observe all the rites enjoined by the Koran. Several Saiyids have gone through a college course, and have risen to high position in Government service.

3. Moghuls.-Moghuls are of two distinct classes, Persian and Indian. They always place Mirza before their names and Beg after them, and the women add 
Khanum to theirs. They have no great reputation for temperance, but are hard working and liberal. As a class they are well-to-do. They are mostly Shi'ahs in religion, and have a name for carefully keeping the rules of their faith. As they form a distinct community with their own place of worship, the Persian Moghuls have adopted fewer Hindu customs than most other Moslems. The Indian Moghuls are the descendants of the Moghul conquerors of India. Many of them have pedigrees and traditions tracing descent from the Mirzas or Timurian princes who were obliged to leave Kabul and fly south from Hamayun's vengeance. In religion the Indian Moghuls are Sunnis.

4. Pathans.--Pathans are of Afghan origin, and their name probably means "highlander." The men add Khan to their names, and the women Khatun. They are of two classes-old settlers, and newcomers from Afghanistan. The descendants of the old settlers have in most cases lost their peculiarities by intermixture with other classes. They are less shrewd than the Shaikh, but more thrifty, headstrong and hot tempered, with a bad name for greed, as a saying likens the merciless creditor to the Pathan. The Urdu proverb says, "There is no trust in a Pathan's word." They are all Sunnis in religion. The unlettered among them carry their religious fervour to fanaticism. But, except the newcomers, as a class they pay little attention to religious duties.

5. Konkanis.-The predominating element in the Konkanis' ancestry is the Arab. Their forefathers, according to tradition, were classed as nawatis (shipmen). These sailors fled to India in 699 to escape the persecution of Al-Hajjaj-ibn-Yusuf, Governor of Al 'Iraq, and settled along the western coast of India from Goa to Cambay. On their arrival they intermarried with the Hindus of the coast, whom they converted to their faith, adopting themselves, many of their habits and customs. Later, between the ninth and sixteenth centuries, they freely intermingled with the Arab and Persian merchants who settled in the coast towns. The precise date of their arrival in the island of Bombay is uncertain. They came 
there from several places on the western coast. They had for years followed the trading and seafaring professions, and, having purchased lands from the Portuguese, they set to work to raise extensive cocoanut plantations. The Konkanis acknowledge no religious head, and the Qazi of Bombay, although possessing some social influence, is officially little more than the registrar of marriage and divorce records. Although the Konkani Moslems have earned a reputation for obstinacy and love of litigation, they are universally regarded as devout and charitable. There is a saying, now become almost proverbial, to the following effect: "Have but the smallest transaction with a Konkani, and you will involve yourself in litigation to the third generation." Many members of the upper class are men of culture and sterling honour, while the lower classes, the mechanics, lascars, messengers, and clerks are sober, industrious, and extremely enterprising.

6. Arabs. - As a class the Arabs are poor. Their newcomers, from the southern and western coasts of Arabia are generally of the Shafi ${ }^{6} i$, and those from Muscat and the eastern sea-board, of the Hanbali school. All newcomers are marked by zeal for their religion. Arabs marry freely with other Sunni Moslems, and have no special or religious organisations. As a class, they do not approve of western education.

The local Moslems who are entirely of Hindu descent are :-

1. Bohras.-The original places where the Bohras were converted are Cambay, Patan, Aurangabad and others. Some Bohras claim to have come of Egyptian and Arab ancestors. The date of their conversion is fixed at about 1067 by a Yamani Dai' named 'Abd Ullah, who was sent to India by the chief Imam of the Musta'li Isma'ili sect. Two stories are told of this Dai's first missionary success. According to one, he gained a cultivator's heart by filling his well with water; according to the other, he won over some of the priests, by dashing to the ground an iron elephant hanging in mid air in one of the Cambay temples. After this the missionary is said to have gone towards Patan, the capital of Gujarat 
at the time. The ruler, anxious to see the stranger, sent a force of men to bring him to the capital. Finding the saint surrounded by a wall of fire the troops retired. Then the king himself came, and in obedience to the stranger's command the fire opened and let him pass. Full of wonder, the king asked for one further sign that the new belief was better than the old. His wish was granted, and one of his holiest idols declared that the Arab's was the true religion. Hearing these words, the Hindus, king and subject alike, embraced the new faith. For two centuries and a half there was nothing to check the Isma'ili or Shi'ah faith. But with the establishment of Muzaffar Shah's power, the spread of Sunni doctrine was encouraged, and the Bohra and other Shi'ah sects repressed. Since then, they have passed through bitter persecutions, meeting with little favour or protection until they found shelter under British rule. The chief event in the history of the Bohras is the transfer of the seat of the Chief Imam of their faith from Yaman to Surat.

There are four schisms from the main body of Bohras - the Ja'fari, the Sulaimani, the 'Alia, and the Nagoshi. Of the Ja'fari schism the seceders became Sunnis. The origin of the Sulaimani sect was that in the sixteenth century a Surat Bohra sent a missionary to Arabia, where he succeeded in making many converts who for a time considered the Surat Dai' as their head. But upon the death of the Surat Dai' in 1588, the Gujarat Bohras chose as his successor one Daud-ibn-Qutub-shah. Meanwhile one of the Yaman Bohras, Sulaiman, on the strength of a letter said to be from the high priest, was accepted as his successor by the people of Yaman. He came over to Surat, but finding his claims rejected by all but a very small body, retired again to Arabia. Such of those Bohras as have upheld his claims were called Sulaimanis.

The Daudi Bohras, the main body of the Shi'ahs, are the richest, best organised, and most widely spread class. They are scrupulous to use no intoxicating drug or stimulants. They are noted for their love of display in house furniture and ornaments. As a class they are 
quiet, clean, tidy, hard working and sober. They are prosperous and many of them are rich; the poor are thrifty and are free from debt, and the unfortunate are maintained from a common fund. They are attentive to their religious duties, and many, both men and women, know the Koran. They are careful to say their prayers, to observe Muharram, and to go on pilgrimage to Karbala and Mecca. Though fierce sectarians, keenly hating and hated by the Sunnis, their reverence for 'Ali and their high priest seems to be further removed from adoration than among the Khojas. They would seem to accept the ordinary distinctions between right and wrong, punishing adultery and other acts generally held disgraceful. Of the state after death they hold that, after passing a time of freedom as bad spirits, unbelievers go to a place of torment and only believers of the Isma'ili faith, after a term of training, enter a state of perfection. Among the faithful, each disembodied spirit passes the time of training in communion with the soul of some good man, and may learn from his good deeds to love the right; spirits raised to a higher degree of knowledge are placed in communion with the high priest, and on his death are with him united to the Imams, and when, through the Imams, they have learnt what they still require to know, they are absorbed in perfection. They seem to share all the ordinary Indian beliefs in spirit possession, exorcism, charms, and omens.

The Sulaimanis have the seat of their head Mullah in Yaman. They do not differ much from the Daudi, with whom they associate but do not intermarry. This community have made many changes and improvements in the last forty years. They can claim to have supplied Bombay with its first Moslem barrister, solicitor, doctor, and engineer. The late Mr. Justice Badr-ud-Din Tayibji, a Judge of the Bombay High Court, was a member of this community.

2. Maimans. - This word is a corruption of Mu'mineen or Believers. Maimans are descendants from converts of the trading Lohana and the market-gardening Kachhi castes. The history of their conversion is that Maulana 'Abd-ul-Qadir Muhyi-id-Din Ghilani, the saint of saints, 
when on his death-bed, ordered Taj-ud-Din, one of his sons, to settle in India and display to its people the light of Islam. Saiyid Yusuf-ud-Din Qadri, fifth in descent from Taj-ud-Din, was in a miraculous dream ordered to set sail to India and guide its people into the right way of Islam. When Saiyid Yusuf-ud-Din reached Sind, its chief received him with honour and entertained him as his guest. At this time Manekji, the head of the Lohana community, was in favour at the court of Markab Khan, the chief, who became a follower of Saiyid, and Manekji with two out of his three sons and 706 Lohana families followed their ruler's example. On their conversion the saint changed the name of the community from Mota and Lohana to Mu'min. The Hindu relations of the converted Lohana called on their spiritual guides to pray to Darya Pir, the Indus, to remove the saint. The Indus heard their prayer. The saint refused a grant of land, and after receiving his followers' assurance that they would continue to support his descendants as their religious heads, Yusuf retired by sea to Al 'Iraq. Before leaving he blessed his people, a blessing to which the Maimans trace their fruitfulness and success. The Kachh Maimans are a fair people who wear the moustache short according to the Sunna (i.e., practice of the Prophet). The elder men and women try to disguise grey hair by dyeing it with henna. Both women and men blacken their eyelids with collyrium. In business the Maimans are shrewd and energetic. Socially, they are jovial, pleasure-loving, and hot tempered. They are regarded by other Moslems as devout and charitable. A favourite form of Maiman charity is to help poor pilgrims to go to Mecca. Fundness for secret charity is an honourable trait among rich Maimans. The Maiman ideal of hidden generosity was the merchant Hajji Zakariyya, the founder of the Zakariyya Mosque in the street of that name in the city of Bombay. A learned and devout maulvi lodging in Zakariyya Masjid was conscious during the night that a bent old man, muffled in a dirty sheet, was shampooing him. The maulvi prayed the old man to cease, but he would not. The maulvi fell asleep, and in the morning found a twenty- 
rupee note under his bedding. As he failed to trace the giver, next night, when the old shampooer returned, the maulvi feigned sleep, and caught the old man's hand while placing a paper under his bedding. In the struggle the old man's sheet fell off, revealing the honoured features of Hajji Zakariyya, who was abashed at being caught in an act of secret generosity. The paper enclosed a note for a hundred rupees. On the wrapper were the words: "A tribute of respect for learning. Pray for the forgiveness of this humble instrument of Allah's will."

Maimans are Sunnis of the Hanafi school, to which most of the Indian and Turkish Moslems belong. As a class they are religious, though some of them keep to early non-Moslem social usages. The most notable of these non-Islamic customs is their refusal, like their ancestors the Lohana, to allow their daughters and widows any inheritance. So careful are the Maimans to perform the pilgrimage to Mecca that about 40 per cent. of their number have the honourable prefix of Hajji. As soon as he has laid by enough money, a Maiman takes his wife and sometimes very young children, and, undaunted by the dangers of the voyage-for He Who cares for him at home will guard him on the way to His House--starts for Mecca, and, if he can afford it, Medina. If he has wealth and leisure, the Maiman pilgrim visits Baghdad to worship at the shrine of his patron saint, Maulana 'Abd-ul-Qadir Ghilani. Like other Sunnis, his belief in magic and sorcery centres in the traditional maxim, "Magic is true, but he who practises magic is an infidel." To the practice of white magic, soothsaying, and the procuring of luck-charms and amulets, they have, like other Moslems, no objection. They also believe in astrology and consult astrologers, a practice condemned by Mohammed. Their advisers in soothsaying and witchcraft are poor Saiyids. The Maiman is not an envied customer of the Bombay tradesman, for he is strict in his observance of the Sunna, which commands him to haggle till his forehead perspires, just as it did when winning the money. At present the Maimans indulge in every kind of trade, from shopkeeping, broking and peddling to furniture-dealing and timber-dealing, 
and they include among their numbers some of the richest individuals in Bombay.

3. Khoja.-The Khojas are scattered over almost all India, and they may be found in Bahrein, Bundar 'Abbas, Mina, Turkish Arabia, and Arabia proper. There is also a flourishing Khoja colony in Zanzibar. The Khoja are Isma'ili of the Nazarian subdivision, who separated themselves from the Bohras on a question regarding the succession to the throne of the Fatimite Khalifah in Egypt, Nazar, the eldest son of Al-Musta'sim Billah, whose cause was energetically promoted by Hasan Sabah, an Isma'ili missionary. Hasan founded the order of Fidawis or devotees, known in Europe, probably from their leader's name, as Assassins or Hashshasheen. Hasan concentrated his powers at Alamut. After gaining Alamut, he resolved to cease acting as Dai' or missionary and political emissary of the Fatimites, and, though he did not yet arrogate to himself the title of the Unrevealed Imam, he made himself known by the convenient title of Shaikh-ul-Jabal, which two of his immediate successors continued to have. Before his death, Hasan had the satisfaction of having his Order flourishing and bidding fair to undermine by his Fidawis' poignard, as well as by the levelling force of his doctrines, the neighbouring monarchies of Islam. His successors, becoming the terror of kings and the authors of revolutions, ruled from the confines of Khorasan to Syria. Hasan, the fourth on the pontifical throne of Alamut, threw aside the mystery by which the son of Sabah had deemed it politic to surround his doctrines. He declared himself the Unrevealed Imam and preached that no action of a believer in him could be a sin. He is called the " Ruler of the world who loosed the bonds of the law." No Khoja mentions his name without the words, "Ala zikerihis-salaam, "Peace be to his name."

It is through this Hasan that the Aga Khan traces his descent from 'Ali. The Indian Khojas believe that Hasan was their first Imam who sent a missionary to India. His name was Nur Satagar, and he made a number of converts by ordering the idols of a Hindu temple to speak and bear testimony to the truth of his mission. 
The name of Nur Satagar, "Teacher of pure light," which he took in addition to his own name, and the practice of the Hindu abstractions, or samadhi, show the process by which the first Isma'ili preachers succeeded in converting Hindus. The Isma'ili preachers gained their chief success among the Lohana tribe. According to the tribe legend preserved by the Khojas, the Lohana are descended from Lava, a son of Rama.

At the middle of the sixteenth century the backsliding of the Panjab Khojas to the Sunnis showed the need of a vice-pontiff in India and not at Alamut. The Imam summoned one Daud, a descendant of a powerful Khoja family, and invested him with the mantle of a Pir. The day of Daud's investiture is still celebrated by the Khoja as the Shah's 'Id. The Pirship became extinct with the death of Daud's son, the deputy of the Imam being henceforth styled Wakil. In 1884 the Khoja Imam Aga Shah Hasan 'Ali, discontinuing the appointment of local Khojas as his Wakils, sent his nephew as his deputy. A year later Aga Shah Hasan 'Ali, better known as His Highness the Aga Khan, himself came to India, and was the first Isma'ili Unrevealed Imam to settle in this country.

The Khojas' Islamism is Shi'ah. To the simple Sunni Kalima or formula of faith : "There is no God but Allah and Mohammed is his prophet," the Shi'ah adds " and "Ali the Companion of Mohammed is the Vicar of God." The elevation of 'Ali to an almost equal place with Mohammed is the distinctive tenet of the Shicah. To revere 'Ali as the Vicar, still more as the incarnation of Allah, to go on pilgrimage to Shah Najf, the supposed place of 'Ali's martyrdom, and at Karbala to bow the forehead on moulds of Karbala's clay and drink the holy clay dissolved in water, are meritorious practices in the eyes of the Shi'ahs. In justification of their belief in incarnations, the Khojas put forward the argument about the Godhead in man that is furnished by a tradition which they attribute to Mohammed: "I am the mimless Mohammed. This is Ahad, the One and Unique Allah." (That is, Mohammed without its three $\mathrm{Ms}$, or mìms, becomes Ahad.) The Khojas are fond of the sayings of 
Mohammed. They pray three times a day, when they repeat the ninety-nine or 101 names of Pir Shah on a rosary. Shah means king, and allegorically stands for God, and Pir the Prophet. They also repeat the names of all the Imams down to the present one. They pray sitting and address their prayers to the Imam. The new moon, Muharram, and Ramazan prayers are repeated in the Jama'at Khana with the Pir. While the prayer-reciters are assembling, a man stands at the chief entrance of the Jama'at Khana demanding the Khoja shibboleth or watchword of every person seeking admission. The newcomers say : Ai Zinda ("O Thou Living One"), and the janitor answers: Qiyam paya ("I have found Him alive and true"). Next in importance is the Khojas' sacrament, the Ghat path or heart prayer. Except on holidays, Mondays, and Saturdays, the sacrament is held after the morning prayers at the chief Jama'at Kana, when Karbala clay is dissolved in a large bowl of water, and as each of the assembly rises to leave the lodge, he goes to the person presiding, lays before him from two annas to two rupees, and kisses his hand. He receives a small cup of the sacramental water, which he drinks and then retires.

The Khoja enjoys a good business reputation. A Parsi would rather trust a Khoja than a Maiman. He is a good hater : "For hate a Khoja, for pain a boil." Though called unbelieving epicures, the Khojas have great regard for their religion. They are neat, clean, sober, thrifty, ambitious, and in trade enterprising, cool and resourceful. The first Moslem baronet in Bombay is a Khoja, who was raised to this dignified rank a short time ago.

4. The Julhais, or weavers, and others of the lower classes, such as the Chilichors, or hack victoria drivers and the mill-hands, are descendants of Hindus of many castes, converted to the Shi'ah faith by different members of the Isma'ili Saiyids. The men are silk and cotton weavers, dyers and cloth dealers, cart and carriage drivers. The women weave and prepare thread. Not over honest or truthful, they are hard working, sober, tidy, niggardly in their thrift, and quarrelsome. They 
are not religious. Some of them are said to worship Hindu gods stealthily. Hindu names are also common among certain classes of them, and while with some of them marriages take place according to the Moslem rule, others, in addition to the Moslem marriage ceremony, call in a Brahmin and go through the Hindu ceremony. In some quarters their marriages take place at a very early age, sometimes before the children are weaned, and they follow the Hindu practice of holding a high festival when the bride comes of age and goes to live with her husband. None of the lower classes has risen to any high position, nor are they very interested in education, and some of them are always in the hands of the merciless moneylenders.

Bombay.

Paul J. E. Damishry.

The various missionary societies, about fourteen in number, the work of which is concerned with the non-Christian residents of Bombay, direct most of their time and attention to the Marathi, Gujarati, and English-speaking peoples of the city. None of them professes to be doing any work among the 167,677 Moslems whose language is chiefly Urdu. The Church Missionary Society started a Moslem mission in 1855 but, owing to straitness of means and other claims, two years ago it handed it over to the Society for the Propagation of the Gospel. This mission, with its rather antiquated methods so strongly in contrast with the splendid Delhi Mission of the same society, is represented by the writer of this article, whose mother tongue is Arabic, and who is working here only temporarily, and two others, who are hardly equipped for an Urdu mission in a place like Bombay. At present it has neither schools, nor zenana workers, nor industries, nor hostels. We, who are looking forward for the second appearing of the Lord, ought not to faint in constantly praying for Bombay, and we ought to learn to give as much as in us lies of our substance to further the cause of the Kingdom of Peace, in which the Moslem may share with us that perfect freedom of which Islam has deprived him. What I long to see in Bombay is a strong mission centre with a wholesome Christian atmosphere where the Moslem inquirer can learn from living examples the teaching of the Gospel of Salvation. The results of such a work will be commensurate with the actual and good quality of work accomplished. Up to this we have not been able to reach the higher class of Moslems. Had the mission had more men, the results would have been incalculable.

Although the Moslem of to-day is far more liberal-minded than he was ten years ago, yet he is possessed of enough zeal for his religion to hamper our insignificant progress. I could relate scores of incidents where a Moslem zealot has impeded my work either by bitter hatred of Christianity or by blind fanaticism. In the month of August of this year two orphan brothers came to me for daily instruction. The 
elder of them, who had made the pilgrimage to Mecca, was twenty-two years old, and the younger was about twelve, but when the secretary of the Moslem Anjuman discovered that $I$ was taking an interest in these two lads he laid hold of them, gave them money and clothing and keeps them in his custody.

It is true that western civilisation and missions as well as the reviral of Hinduism are causing the religious vitality of Islam to decline and decay, but Moslems are not unconscious of this, and their various associations are not only largely occupied in reforming the social system, but they are to a certain extent absorbed in political and national affairs. Their leagues and associations are defensive organisations rather than anything else. And yet the ranks of the Moslem community in Bombay, though not aggressive by means of religious propaganda, are being reinforced every day by hundreds of co-religionists from almost all parts of India and Arabia. The increase of the Moslem population between the census of 1901 and that of 1906 is shown as 12,930 .

P. J. E. D. 